\title{
Service Quality And Spectator Satisfaction On University Sporting Grounds
}

Michael Cant, University of South Africa, South Africa

Jan Wiid, University of South Africa, South Africa

\begin{abstract}
The main aim of this study was to investigate the quality of service experienced by spectators at a sporting event, as well as to establish if there is a relationship between a core sport product and the product servicescape in conjunction with spectator satisfaction. The study also investigated the perceived value that spectators receive from the total sport product, which forms an integral part of the total market offering to spectators. It is important to establish this relationship as it will have an impact on future attendance of these types of events. In order to achieve the objectives of the study, a survey was distributed to spectators who watched soccer and basketball games on the grounds of a particular university. The respondents were exposed to the services, staff and activities in and around the stadium before, during, and after the matches to ascertain total satisfaction of the sporting event.
\end{abstract}

Keywords: Sport Service Quality; Satisfaction; Spectators

\section{INTRODUCTION AND OBJECTIVES}

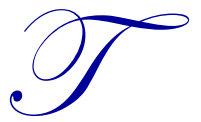

he past years have seen a decline in sponsorships from many local and international companies due to, amongst other things, the worsening economic climate and the pressures that companies feel on the economic front. This has placed further pressure on the professional sporting events industry which is becoming increasingly competitive due to the range of alternatives they can select as spectator games. Consequently, providers of professional sporting services are increasingly forced to evaluate and re-evaluate their offering to spectators in order to motivate customers to attend games as spectators (Theodorakis, Koustelios, Robinson \& Barlas, 2009). This motivation can be successfully provided and enhanced if the spectators are initially satisfied with their prior experience. Customer satisfaction is crucial in the long-term survival of a business or sport and this is influenced by a number of factors and sport organisations. These organisations are increasingly learning the importance of not taking their customers for granted and treating them as individuals and important valued partners. Sports organisations and the events they present do not differ. Spectators have different reasons for supporting a particular sport organisation and thus need to be catered for accordingly.

Service satisfaction is a function of consumers' experiences and reactions to a provider's behavior during the service encounter; it is a function of the service setting (Abdullah \& Rozario, 2009). In order to reach that level of satisfaction, commitment from employees is necessary as they facilitate the service encounter. Sureshchandar, Rajendran and Anantharaman (2002) suggested that customer satisfaction comprises of the following factors: core service, human element of service delivery, systematization of service delivery, tangibles of services, and lastly, social responsibility. These components may define the behaviour intentions at sporting events. Research considers customers' favourable intentions to (a) recommend the team to other customers, (b) attend the team's future sporting events, and (c) remain loyal to the team (Yoshida \& James, 2010).

Previous research studies, such as Abdullah \& Rozario (2009), Yoshida \& James (2010), and Robinson \& Barlas (2009), support this conceptualisation and provide the basis for the conclusion that the core product in sports is derived from sport-related factors, such as the quality of the home and opposing teams. Winning percentage of a team, their place in the standings, the team's history, the number of star players on the team, and the reputation of the team are also important factors that impact on spectator satisfaction. The core product in spectator sports 
includes game-related components, which are key determinants of whether an element is the core product or ancillary service (Yoshida \& James, 2010).

Although researchers (Theodorakis, Kambitsis, Laios \& Koustelios, 2001) generally agree that there is an actual relationship between the two constructs, the direction of this relationship has been the subject of debate. Therefore, the objectives are as follows:

- $\quad$ To investigate the relationship between the core sport product and spectator satisfaction

- $\quad$ To investigate the relationship between the servicescape product and spectator satisfaction

- $\quad$ To determine the perceived value that spectators receive from the total sport product

\section{OVERVIEW OF SERVICE QUALITY}

\section{Service Quality Defined}

In recent years, service quality has become one of the great differentiators for companies' dealings with customers and spectators. Potluri and Zeleke (2009) explain that with the economic hardships and realities since 2008, companies have been forced to become more focused on the needs of the customers and meeting their expectations, and it has turned out to be very crucial, especially in those organisations in order to retain them. Service quality is influenced by expectation, process quality, and output quality. In other words, the standard of service is defined by customers who have experienced that service and used their experiences and feelings to form a judgment (Abdullah \& Rozario, 2009).

Literature offers a number of service quality models, but one that is widely accepted and used is the SERVQUAL model developed by Parasuraman, Zeithaml and Berry (1988). This model highlights five service quality dimensions; namely, reliability, assurance, tangibles, empathy, and responsiveness. Reliability, as Kouthouris and Alexandris (2005) observe, refers to the ability to perform the promised service dependably and accurately. Assurance refers to employees' knowledge and their ability to convey trust and confidence. Tangibles refers to the physical environment. Empathy refers to employees' willingness to provide individualised attention to customers, and responsiveness refers to employees' willingness to help customers and to provide prompt services. Jae Ko \& Pastore (2007) stress that to be competitive in the very competitive sporting event's market environment, sports organisations need to increase customer satisfaction by providing consistently high quality services. Zeithaml and Bitner defined perceived service quality as a global judgement or attitude relating to the superiority of a service. Since the perception of the quality of the service received will differ from one spectator to another, it is clear that these perceptions could occur at multiple levels in an organisation (Sureshchandar, Rajendran \& Anantharaman, 2002).

Chelladuri and Chang (2000) identified the targets of service quality that ultimately influence the overall satisfaction that spectators have with the sport as (a) the core product; (b) service co-production and (c) sportscape features. Each of these is discussed in the following sections.

\section{The Core Sport Product}

The term 'core sport product' refers to those elements of the spectator sport service experience that directly involve the sporting contest (Mullin, Hardy \& Sutton, 1993). The core sport product is what makes people come to the stadium and it involves the activities that produce the entertainment for which they are willing to pay (Westerbeek \& Shilbury, 2003).

Morgan and Summers (2005), however, refer to the core sport product as the competition itself, as this is the main reason people spend money to attend sporting events. Like any product, the sport product is seen as also consisting of three product levels which together all enhance the total product experience. These levels are depicted in Figure 1: 


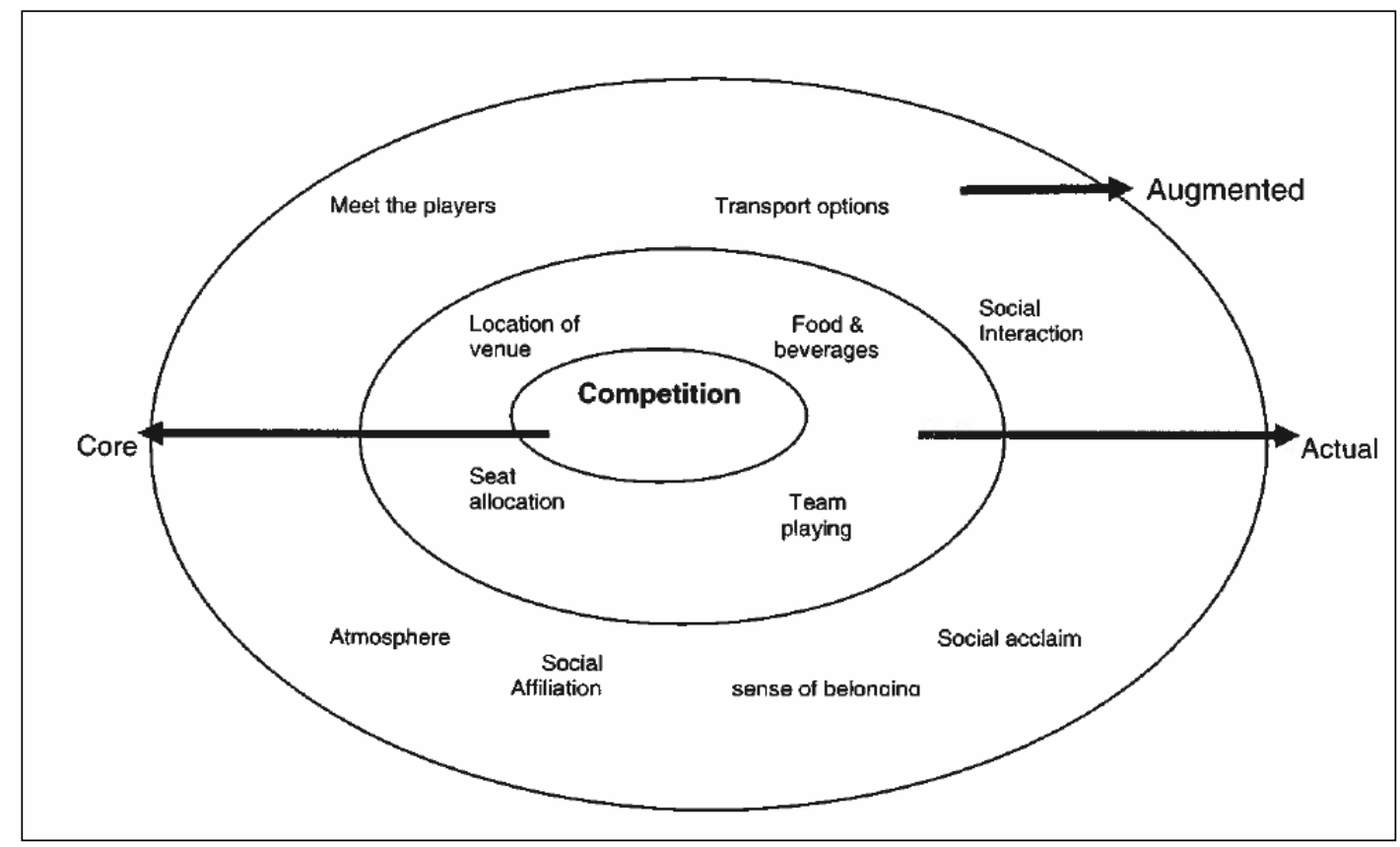

Figure 1: Product Levels For A Sporting Event

Source: Morgan \&Summers (2005)

As specified in Figure 1, competition, by its very nature, is completely uncontrollable and unpredictable and is therefore key to the passionate and committed following of many sport fans. Spectators can be satisfied with their experience, even if their team does not win, as long as the quality and intensity of competition is of a high standard (Morgan \& Summer, 2005). The actual products and the augmented products simply enhance the entire experience, which then affects and impacts spectator satisfaction. Sports marketers can thus use past performances of the team in any marketing communication initiatives to intensify the expectation that fans have of the core product.

\section{Fan Identification And Social Identity}

According to Grencer (2011), the emotions and feeling of spectators form a significant part of the sports product. Customers typically make emotional investments toward organisations that, for example, support sports teams and become members. Westerbeek and Shilbury (2003) mention that identification of fans varies from religious follower to hedonistic fan. The religious follower views the core product (competition) as a religious ceremony, whereas the hedonist's view of a sporting event is that fans should simply have a good time. This viewpoint indicates that each team has an equal opportunity of winning and therefore is not necessary to fuss over one team.

Fan identification is defined as the personal commitment and emotional involvement customers have with a sport organisation. Individuals with a strong degree of identification to their team consider the success or failure of their team as their own. Such individuals bear their teams unceasingly. Gencer (2010) is of the opinion that when managed effectively, this condition presents professional sports teams the prospect to acquire enviable advantages.

Studies in the identification literature are grounded in social identity theory. Social identity theory states that people tend to classify themselves and others in various social categories. These categories allow people to segment and order their social environment and they provide a means of classifying themselves and others in it (Greer \& Tomas, 2009). Social identification itself, as Ashforth and Mael (1989) explain, is the perception of belonging to some human aggregate. It is therefore interesting to investigate whether fan identification with a particular sport or sports team can influence the level of satisfaction that fans may experience with regard to that particular sport or sports team. 


\section{Fan Involvement}

Meenaghan (2001) suggests that because fan involvement forms part of the social identity theory, it has been recognised as "...the extent to which consumers identify with and are motivated by their engagement and affiliation with particular leisure activities." The Hunt et al. (1999) typology is based on the source of motivation and on behaviour exhibited by the different types of fans. The fans were distinguished based on the types of motivation; namely, situational motivation and enduring motivation. Situational motivation is bound by time and space and is therefore more temporary in nature, while enduring motivation is a result of the fan perceiving the sports object as important to his or her self-concept (Westerbeek \& Shilbury, 2003). These fans are ranked as temporary, local, devoted, fanatical, and dysfunctional. Temporary fans will be less involved in the game and will support the sport only based on a temporary phenomenon. On the other hand, fanatical fans take their support onto another level. They are more than loyal and feel the sport object to be as important as a means of self-identification which they demonstrate in different forms of supportive conduct (Westerbeek \& Shilbury, 2003).

\section{Service Co-production}

Sportsmen do not bear the sole responsibility in producing a satisfactory atmosphere for a sporting event. The employees and sports spectators each bear significant responsibility in the total satisfaction of the sporting event. The employees have the duty to produce friendly service to spectators and treat them as individual customers with unique individual needs. Sports spectators also play a role in ensuring complete satisfaction for other spectators. This may be achieved by them choosing to engage in conversation and give their personal opinions on the sporting event. In addition, cheering, clapping of hands, and singing can also contribute to uplift the social environment.

\section{Sportscape Features}

\section{$\underline{\text { Servicescape Defined }}$}

Wakefield and Blodgett (1994) mention that one of the main reasons customers attain leisure services is to experience excitement and stimulation. Research indicates that the degree of arousal or excitement that customers experience while consuming the leisure service may be a major determinant of their subsequent satisfaction with the service experience. The servicescape can either enhance or suppress these emotions and is therefore important in this experience (Wakefield \& Blodgett, 1994).

Servicescape is a term used in reference to the physical surroundings to facilitate the service offering to consumers. This is inclusive of tangible elements, such as the infrastructure, and intangible elements, such as temperature or sound, that make up the service experience (Hoffman \& Turley, 2002). Bitner (1992) suggested that servicescape might have an effect on customer satisfaction. He mentioned two important aspects of servicescape in this regard; namely, (a) spatial layout and functionality and (b) elements related to aesthetic appeal.

Spatial layout and functionality refer to the ways in which seats, aisles, food service lines, security, restrooms, entrances, and exits are designed and arranged in the sporting arena. Aesthetic appeals refer to factors such as the surrounding environment, cleanliness, signage, and other elements. Based on their perception of these two sets of factors, they will have set thoughts and feelings that lead them to either approach or avoid the sporting event (Wakefield \& Blodgett, 1994). Aspects of the servicescape that can influence spectator satisfaction within a sporting environment context will be discussed in the following sections.

\section{$\underline{\text { Safe Atmosphere Ensuring Satisfaction }}$}

Westerbeek \& Shilbury (2003) observe that the safe atmosphere dimension relates to safety issues in and around the stadium. As mentioned previously, there are different types of fans present at the stadium. Dysfunctional fans are those whom the sports object are a primary method of self-identification. This attachment may lead to irregular behaviour such as violence. This implies that organisers must ensure that there is ample security within the facilities to ensure the safety of all spectators. 
The Australian Institute of Criminology (2010) has reported that spectator violence in stadiums is an increasing concern. Spectators need to feel safe in the sporting environment in order for them to fully enjoy the event. Security personnel should be made available to ensure that spectators are safe should anything happen and that their cars are well looked after.

\section{$\underline{\text { Hospitality Dimension Ensuring Satisfaction }}$}

Service quality and customer satisfaction is vastly investigated. Theodorakis et al. (2001) investigate the effects of spectators' perceptions of service quality on their satisfaction in a professional spectator sport. Employees at the stadium also play a vital role in ensuring that all activities run smoothly; therefore, it is imperative that they are well trained. Frontline employees are the ones who interact with the spectators and should therefore do all they can to enhance their total experience.

\section{The Stadium Arena Facilitating Spectator Satisfaction}

Correia and Exteves (2007) stated that spectators would be satisfied and happy when there are stadium facilities, car parks, safety, and ticket counter space. Thus, there are various factors that can influence spectators' satisfaction and encourage them to come back to the stadium again for future games (Pilus, Yusof, Bojei, Fauzee, Samah \& Aziz, 2010). For those spectators who share a high degree of self-identification with the team, they may consider the stadium 'Home'. Westerbeek (2001) states that home goes beyond the physical boundaries and features of the sportscape - that it involves emotional attachment to the place where history has been created and memories are stored. It is with these memories that spectators build their confidence in their teams' ability to perform well. Thus, some spectators may prefer their team to play at their 'Home' arena. Therefore, the following hypothesis is set for this study:

$\mathbf{H}_{\mathbf{1}}$ : There is a positive relationship between the core sport product and spectator satisfaction.

\section{OVERALL SPECTATOR SATISFACTION}

Oliver (1997) defines customer satisfaction as a product or service feature or the product or service itself, providing a pleasurable level of consumption-related fulfilment. No longer can organisations afford to take their customers for granted as they can simply take their business elsewhere. Sports organisations are not an exception.

Cronin and Taylor (1992) views customer satisfaction as the overall feeling customers have toward an organisation. This overall feeling can be incredibly beneficial to firms as it leads to positive word-of-mouth, customer loyalty, and cross-buying. However, for sports spectators, customer satisfaction has been viewed as a significant predictor of intentions to attend future sporting events (Yoshida \& James, 2010).

Spectators may be satisfied only when they truly believe that they have received value for their time and money. The core sport product (competition) may create such value. The excitement, crowds cheering, and social interaction from the stadium could also create the sense of value that spectators crave.

\section{Perceived Value From The Spectator Sport Experience}

Westerbeek and Shilbury (2003) suggest that spectators receive value from each element of sport quality. From the core product (competition), one perceives value as emotional. The intensity, quality and standard of the sportservice can leave the spectator extremely emotional. Whether their team wins or loses, each type of fan will undergo a number of different emotions, be it joy, anger, suspense or contentment.

The perceived value from the service co-production comes in the form of practicality. Employees at the sports arena may contribute to the total value received. A simple smile or friendly assistance can go a long way in creating a good environment. Unlike with core product and service co-production, servicescape value is not dependant on players or employees. Either equipment works or it does not; sporting facilities are either available or not. It is therefore important that everything required for a sporting event is in good working condition. Mishaps can cause the stadium, as a brand, its reputation and discourage spectators from any association with it. 
Yusof (2008) investigated the relationship between spectator perceptions on sportscape and spectator satisfaction. This study concluded that there is, in fact, a relationship between these variables; therefore, it is hypothesised:

$\mathbf{H}_{2}$ : There is a positive relationship between the servicescape product and spectator satisfaction.

\section{RESEARCH METHODOLOGY}

\section{Participants}

The sample in this study consisted of a range of spectators (male and female) of sports events (basketball and soccer) that had been exposed to two or more live matches. A total of 201 correctly completed questionnaires were obtained.

\section{Procedures}

Due to the nature of sporting events at the university level - where season tickets or tickets for a match are not sold in advance - a sample frame does not exist for such events and very little is known about the population before the study is conducted. The population from which the sample is drawn is the spectators who attended the matches on the specific days during which the research was conducted.

Recognising the nature of the population at sport matches, a non-probability convenience sample method was chosen. Such methods do have limitations, such as presenting a higher probability of not being representative of the target population. However, the nature of the population under study, as well as the objective of the study which is on testing an existing sport service model rather than making inferences to a larger spectator population, makes the method suitable for the study.

Respondents were chosen before, during half time, and at the end of each game to avoid the potential bias owing to the use of non-probability sampling. Respondents were approached from in and around the stadium and had to be exposed to two or more live matches to be included in the study. No incentives were provided to respondents to complete the survey.

Using a self completion questionnaire, respondents had to rate statements on a 5-point Lickert scale ranging from Strongly Disagree to Strongly Agree. The questionnaire consisted of 24 service-related statements, an overall customer satisfaction statement (also using a 5-point scale ranging from Very Dissatisfied to Very Satisfied) and two questions asking whether the respondent is a soccer or basketball spectator.

The statements in the questionnaire are based on those used in the Sportserve model. The questionnaire items are testing six sub-dimensions; namely, Tangibles, Responsiveness, Access, Security, Reliability, and Core relating to the stadium, staff, facilities, and the game played.

\section{RESULTS}

\section{Reliability}

A number of tests can be used to determine the internal consistency and repeatability of results in a survey. This is done by testing two different parts of the same instrument in a process that average the correlation between every possible combination of questionnaire statements used in the study.

For a multi-item scale, such as the Lickert Scale used in this study, Cronbach's Alpha (a coefficient between 0 and 1) is used to test for internal consistency. A coefficient that is too low (below 70\%) shows that respondents likely interpret the meaning of statements differently, and with a coefficient that is too high (above 0.9), it is likely that some statements used in the study are too similar and can be removed from the measuring instrument. 
The study scored 0.878 against the international norm for reliability using Cronbach's Alpha, which is $70 \%$. This means that the research questionnaire is reliable in that repeated surveys in the population should lead to very similar results. For each of the sub-dimensions, the following reliability scores were obtained: Tangibles 0.698; Responsiveness - 0.842; Access - 0.647; Security - 0.858; Reliability -0.787 ; and Core -0.496 . The results show that improvements can be made to the two statements under the Access sub-dimension as well as the three statements under the Core sub-dimension.

This study can be viewed as having content validity as none of the items measured were difficult to define. It is highly unlikely that each item measured was not understood in a uniform manner by the respondents completing the questionnaires.

\section{Data Analysis}

The basic data characteristics are obtained through descriptive statistics. The data set recorded an overall mean of 3.458 out of 5 (median is 3.542) which, in percentage terms, is an average of $69.16 \%$ recorded for all the statements amongst all the respondents. All statements were stated in a positive manner, meaning that every statement was evaluated on how each respondent agrees on the positive aspects of the statement. For example, statements regarding staff were stated on how polite, willing to help, and how prompt they are rather than on how rude, unwilling to help, or slow in their service.

An overall standard deviation of 0.974 was recorded for the data. Considering a data range of 1-5, most scores would fall within two standard deviations of the mean, affirming the mean as a good indicator of the average score. The overall standard error of 0.068 indicates at least a $68 \%$ chance that the population mean for all spectators at these sport matches tested would be between 3.39 and 3.526 .

Table 1 provides an overall picture of how the spectators in this survey experienced the service as per the six dimensions of the Sportserve model. Spectators rated their experience on a five-point scale.

Note that Option 3 of each statement (Neither Agree nor Disagree) is excluded from Table1 to show the difference in percentage terms between the two negative options (Strongly Disagree and Disagree) versus the two positive options (Agree and Strongly Agree). Table 1 outlines the percentage contribution of the option Neither Agree Nor Disagree (of the total per sub-dimension as tested in the questionnaire). Also note that Neither Agree Nor Disagree represents 0 in Figure 2, but the actual percentages are shown in Table 1.

Table 1: Percentage of Contribution per Sub-dimension of the Option Neither Agree Nor Disagree

\begin{tabular}{|l|c|}
\hline \multicolumn{1}{|c|}{ Sub-dimension } & \% 'Neither Agree Nor Disagree' Response \\
\hline Tangibles & 18.1 \\
\hline Responsiveness & 36.1 \\
\hline Access & 18.9 \\
\hline Security & 21.3 \\
\hline Reliability & 43.7 \\
\hline Core & 14.1 \\
\hline
\end{tabular}

It is evident from the percentages in Table 1 that respondents lack opinions of the stadium employees and staff regarding their responsiveness and reliability. This is likely due to the fact that they did not experience nor interact with staff before, during, or after the games. 


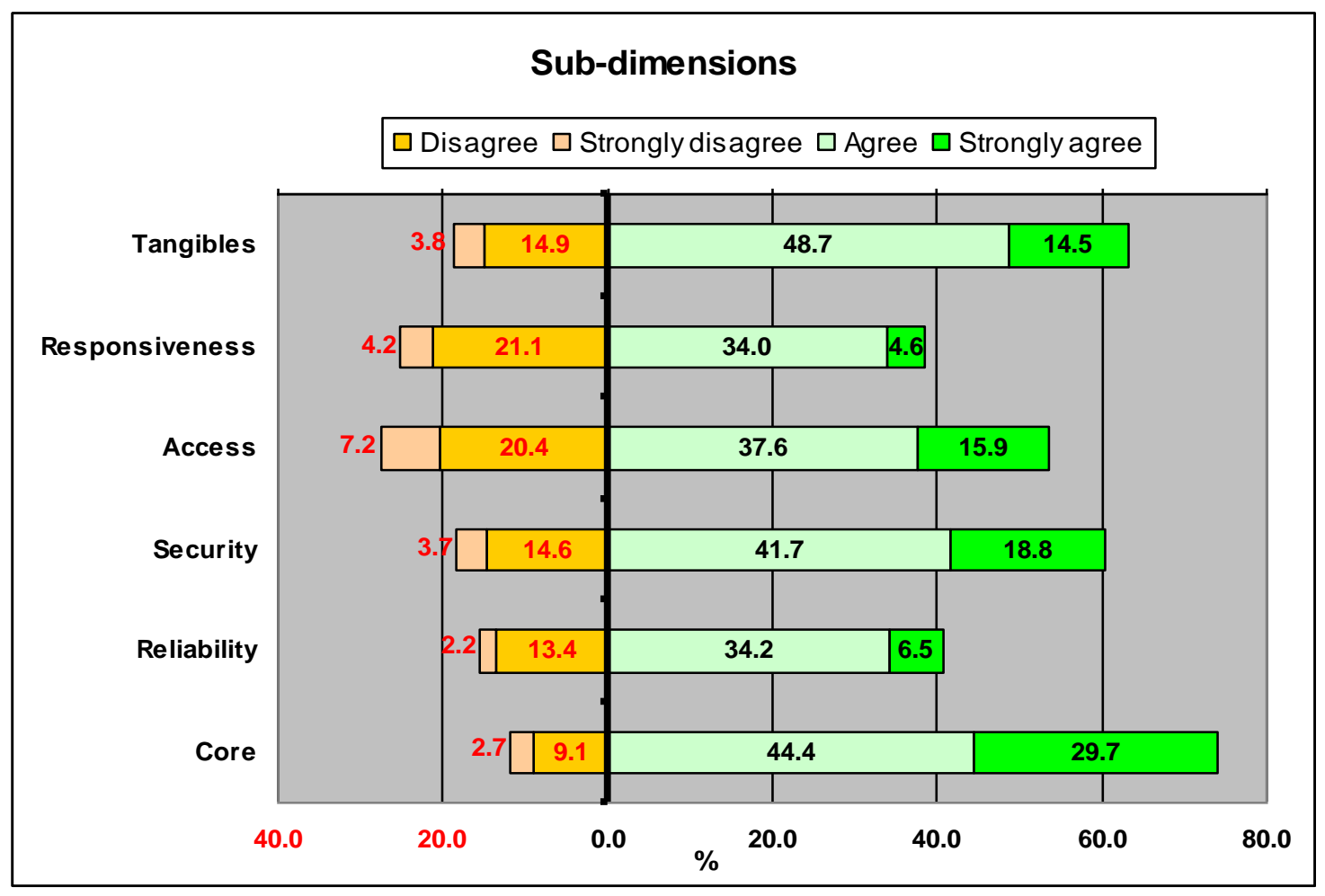

Figure 2: Overall Experience per Sub-dimension

Figure 2 shows that spectators experienced core-related statements (referring to who the winning team is, if the game was played well, and the number of star players on each team) as most positive (74.1\%), followed by Tangibles $(63.2 \%)$ and Security $(60.5 \%)$. It is therefore evident that the high scoring of the core items is that spectators attend a sport match out of interest for the game itself.

Reliability (40.7\%) and Responsiveness (38.6\%), relating to service staff/employees, scored the lowest positive response. These, however, did not score the highest negative response due to the high percentage of respondents that indicated that they were unsure (Neither agree nor disagree with the statement). Access (27.6\%) scored the highest negative response.

\section{Data Fit To Hypothesised Dimensions}

\section{Overall Factor Analysis}

In factor analysis, principal components analysis (Varimax normalised procedure) was used, which is an approach that considers the total variance of data. Factors were selected if their Eigen values were greater than 1.0 and their total variance accounted for more than $60 \%$.

First, an exercise was conducted to deliver free factor analysis on the data which delivered 20 factors. In this free factor analysis, five factors produced Eigen values of larger than 1. This was not used as factor analysis is mainly used to reduce and summarise data and 20 factors did not achieve this objective when assessing 24 statements. In a forced 10 factor exercise, four factors produced an Eigen value of larger than 1.

As the original questionnaire and the Sportserve model itself is dimensionalised into six factors, a decision was made to force the data of this survey into the same number of sub-dimensions to enable comparisons between the original model and the South African research. All six sub-dimensions achieved an Eigen value of higher than 1 and account for $61 \%$ of the variability of the data. The output is listed in Table 2. 
Table 2: Forced Six-factor Eigen Value Report

\begin{tabular}{|l|c|c|c|c|}
\hline \multicolumn{1}{|c|}{ Factors } & Eigen Value & \% Total Variance & $\begin{array}{c}\text { Cumulative Eigen } \\
\text { Value }\end{array}$ & Cumulative \% \\
\hline 1- Security & 6.82 & 28.43 & 6.82 & 28.43 \\
\hline 2- Responsiveness & 2.18 & 9.09 & 9.01 & 37.52 \\
\hline 3- Tangibles & 1.79 & 7.47 & 10.80 & 45.00 \\
\hline 4- Core & 1.45 & 6.03 & 12.24 & 51.02 \\
\hline 5- Convenience & 1.21 & 5.03 & 13.45 & 56.05 \\
\hline 6- Access & 1.14 & 4.76 & 14.59 & 60.81 \\
\hline
\end{tabular}

Evident from Table 2 is that the sub-dimension, Security, explains the highest percentage of variability in the data set $(28.4 \%)$. This is followed by Responsiveness $(9.1 \%)$ and Tangibles $(7.5 \%)$.

The factor analysis portrays a very good fit between the hypothesised and the data-derived dimension. This confirms the high Cronbach Alpha which indicates that this study can be repeated at the same venue, and other venues across South Africa, and will reveal similar results.

\section{Relationship Between Service Variables And Spectator Satisfaction}

The questionnaire used in this study is the same as the one used in the Sportserve model as one of the main objectives of the study is to determine to what extent the existing Sportserve model can be applied to South African circumstances.

The compilation of the questionnaire was not preceded by qualitative research to determine the exclusivity and exhaustiveness of the statements used to determine overall customer satisfaction at sporting events under South African circumstances. The purpose of testing the relationship between service variables and spectator satisfaction is therefore not to isolate variables with the highest predictive value in general, but limited only to those used in the existing Sportserve model.

First, correlation analysis was conducted between each main sub-dimension and overall customer satisfaction. The purpose was to understand possible relationships of these sub-dimensions to overall customer satisfaction. Table 3 outlines the correlation output.

Table 3: Correlation between Sub-dimensions and Overall Satisfaction

\begin{tabular}{|l|c|c|c|c|c|c|c|}
\hline \multicolumn{9}{|c|}{ Pearson Correlations Section (Row-wise Deletion) } \\
\hline \multirow{3}{*}{$\begin{array}{l}\text { Overall satisfaction } \\
\text { Tangibles }\end{array}$} & Satisfaction & Tangibles & Responsiveness & Access & Security & Reliability & Core \\
\cline { 2 - 8 } Responsiveness & $\mathbf{1 . 0 0}$ & 0.46 & 0.35 & 0.36 & 0.45 & 0.45 & 0.16 \\
\cline { 2 - 8 } Access & 0.46 & $\mathbf{1 . 0 0}$ & 0.40 & 0.27 & 0.42 & 0.41 & 0.09 \\
\cline { 2 - 9 } $\begin{array}{l}\text { Security } \\
\text { Reliability }\end{array}$ Core & 0.35 & 0.40 & $\mathbf{1 . 0 0}$ & 0.19 & 0.37 & 0.57 & 0.20 \\
\cline { 2 - 8 } & 0.36 & 0.27 & 0.19 & $\mathbf{1 . 0 0}$ & 0.41 & 0.32 & 0.08 \\
\cline { 2 - 8 } & 0.45 & 0.42 & 0.37 & 0.41 & $\mathbf{1 . 0 0}$ & 0.53 & 0.16 \\
\cline { 2 - 9 } & 0.45 & 0.41 & 0.57 & 0.32 & 0.53 & $\mathbf{1 . 0 0}$ & 0.28 \\
\cline { 2 - 9 } & 0.16 & 0.09 & 0.20 & 0.08 & 0.16 & 0.28 & $\mathbf{1 . 0 0}$ \\
\hline
\end{tabular}

All sub-dimensions record a positive relationship with each other as well as with overall satisfaction. Although none of the sub-dimensions correlate highly with overall satisfaction, Tangibles (0.46), Security (0.45), and Reliability (0.45) recorded the highest correlation of the sub-dimensions. It should be noted that dimensions are averaged across questionnaire items, so it is less likely for a "dimension" to have a relationship with a questionnaire item than an item itself.

Multiple regression analysis was performed to determine the predictive value of service questionnaire statements (independent variables) to overall satisfaction (dependant variable). The confidence interval for the analysis was set at $95 \%$. The goodness of fit statistics are listed in Table 4. 
Table 4: Goodness of Fit Statistics

\begin{tabular}{|l|c|}
\hline Goodness of Fit Statistics: & \\
\hline Observations & 201 \\
\hline DF & 176 \\
\hline $\mathrm{R}^{2}$ & 0.455 \\
\hline Adjusted R & 0.381 \\
\hline MSE & 0.276 \\
\hline RMSE & 0.525 \\
\hline MAPE & 10.519 \\
\hline
\end{tabular}

In this study, $46 \%\left(\mathrm{R}^{2}: 0.455\right)$ of the total variance of Overall Satisfaction is explained by the model. The model, as a whole, has reasonable predictive capability as the $\mathrm{F}$ value recorded is $6.129(\mathrm{Pr}>\mathrm{F}$ of $<0.0001)$.

\section{MAIN FINDINGS}

It was revealed that "stadium staff/personnel" was the most critical factor needing improvement in both the Responsiveness and Reliability sub-dimensions. Less than $50 \%$ of spectators had a positive view of these service sub-dimensions. Spectators do not think that stadium staff is available to give assistance at all times and, more seriously, only $37.4 \%$ regard stadium personnel as trustworthy.

Factor analysis has shown that the data variability is explained best by the Security sub-dimension recording the highest loadings - all three cover aspects regarding how respondents feel inside, outside, and while moving around the stadium. In the data derived dimensions, the opinion of whether stadium employees are trustworthy is included in the Security sub-dimension.

At on overall satisfaction rate of 3.91, one can conclude that spectators are fairly satisfied with the sports venue. However, the highest score for both males and females was achieved through their rating of the core items relating to the game, teams, and players. Therefore, spectators are more satisfied with the games played (3.89) than with the security (3.57) and tangibles (3.55). These last two statements relate to infrastructure. Of concern is the human element in the service delivery; namely, responsiveness (3.14) and reliability (3.29) - these scored the lowest of all the sub-dimensions tested. In addition to a well-planned structure, ensuring good viewing for spectators and easy entrance and exit, the importance of good service from staff and safety was highlighted through the regression model.

A correlation analysis was conducted between core sport product and overall customer satisfaction. The analysis produced a correlation coefficient of 0.16 , indicating that correlation weak. The alternative hypotheses $\mathrm{H}_{1}$ : There is a positive relationship between the core sport product and spectator satisfaction - is therefore accepted.

A correlation analysis was conducted between the sub-dimensions and overall customer satisfaction. The correlation coefficients are: tangibles - 0.46, responsiveness - 0.35 , access - 0.36 , and reliability - 0.45 . The correlations that exist are meduim as the correlation coefficient varies between 0.3 and 0.5 . Regardless of strength of the correlation, it was determined that there is a positive correlation between the sub-dimensions and spectator satisfaction, thus confirming a relationship. Therefore, the hypothesis $-\mathrm{H}_{2}$ : There is a positive relationship between the servicescape product and spectator satisfaction - is accepted.

\section{CONCLUSION}

The objectives of the research were to investigate the relationship between the core sport product and spectator satisfaction, to investigate the relationship between the servicescape product and spectator satisfaction, and to determine the perceived value that spectators receive from the total sport product. The repeatability of the study was confirmed by the Cronbach alpha of 0.878 . The similarity of factors obtained, compared to the original Sportserve model (with minor exceptions), was confirmed by the factors obtained through the factor analysis. "The view from the seat is good" was the statement explaining the highest predictive value of the Overall Satisfaction. 
The investigation found that spectators are concerned with components of the service experience other than the core product. This supports of the marketing principle that some customers will evaluate not only the core product but also the servicescape in making their satisfaction judgments, even in spectator sports.

When it comes to spectators, organisers of spectator sports on all levels - professional and amateur - need to identify the controllable contributors to spectator satisfaction (servicescape and peripheral service elements. Marketing efforts should focus on these as profitability of the sporting event is dependent on satisfied spectators. The outcome of the sporting event (win/loose) is uncontrollable and not the main contributor to spectator satisfaction.

Research is needed to determine the degree that the elements of the servicescape effect spectator satisfaction amongst different sporting codes and the motivation for attending these sporting events.

\section{AUTHOR INFORMATION}

Professor Michael Cant is CoD of the Department of Marketing and Retail Management at the University of South Africa. He has published over 35 accredited articles in refereed journals and is the editor and author of more than 20 books in marketing. These books are widely prescribed at universities in South Africa. He has presented papers at more than 45 international conferences all over the world and is a well respected marketing and retail scholar. He holds a PhD in Marketing from the University of South Africa. E-mail: cantmc@unisa.ac.za (Corresponding author)

Dr Jan Wiid is a senior lecturer in the Department of Marketing and Retail Management at the University of South Africa. He has published 6 articles in refereed journals and is the editor and author of more than 5 books in marketing. These books are widely prescribed at universities in South Africa. He holds a DCom in Marketing from the University of Johannesburg. E-mail: JWiid@unisa.ac.za

\section{REFERENCES}

1. Abdullah, D. N. M. A. \& Rozario, F. (2009). Influence of service and product quality towards customer satisfaction: A case study at the staff cafeteria in the hotel industry. World Academy of Science, Engineering and Technology, Vol. 53. Retrieved from: http://www.waset.org/journals/waset/v53/v5328.pdf

2. Ashforth, B. E. \& Mael, F. (1989). Social identity theory and the organisation. Academy of Management Review, Vol. 14 No. 1. Retrieved from: http://www.jstor.org/stable/258189

3. Bitner, M. (1992). Servicescapes: The impact of physical surroundings on customer and employees. Journal of Marketing, Vol. 56, pp. 57-71. Retrieved from: http://www.ida.liu.se/ steho/und/htdd01/9208310667.pdf

4. Chelladurai, P. \& Chang, K. (2000). Targets and standards of quality in sport services. Sport management Review, Vol. 3, pp. 1-22. Retrieved from: http://www.getcited.org/refs/PP/2/PUB/103338407.

5. Correia, A. \& Esteves, S. (2007). An exploratory study of spectator's motivation in football. International Journal Sport Management, Vol. 2 No. 6, pp. 572-590. Retrieved from: http://home.fmh.utl.pt/ acorreia/images/pdf/correia_esteves_ijsmm_2007.pdf

6. Cronin, J. J. \& Taylor, S.A. (1992). Measuring service quality: A re-examination and extension. Journal of Marketing, Vol. 56, pp. 55-68. Retrieved from: http://www.4shared.com/office/3QsmDd6U/Measuring_Service_Quality_A_Re.html

7. Gencer, R. T. (2010). The relationship between team identification and service quality perceptions in professional football. African Journal of Business Management, Vol. 5 No. 6, pp. 2140-2150. Retrieved from: http://www.academicjournals.org/AJBM

8. Greer, M. J. \& Tomas, A. (2009). An analysis of fan identification and sponsorship relationships. Retrieved from: http://freedownload.is/pdf/vermont-college-hockey

9. Hoffman, K.D. \& Turley, L.W. (2002). Atmospherics, service encounters and consumer decision making: An investigative perspective. Journal of Marketing theory and practice, pp. 33-46. Retrieved from: http://www.jstor.org/stable/10.2307/41304272 
10. Hunt, K. A., Bristol, T. \& Bashaw, R. E. (1999). A conceptual approach to classifying sports fans. Journal of Services Marketing, Vol. 13 No. 6, pp. 439- 452. Retrieved from:

http://dx.doi.org/10.1108/08876049910298720

11. Ko, Y. J. \& Pastore, D. L. (2007). An Instrument to Assess Customer Perceptions of Service Quality and Satisfaction in Campus Recreation Programs. Recreational Sports Journal, Vol. 31, pp. 34-42. Retrieved from:

http://wspahn.camel.ntcpe.edu.tw/ezcatfiles/t063/download/attdown/0/Dec\%2014\%20questionnaire\%20rec reation.pdf

12. Kouthouris, C. \& Alexandris, K. (2005). Can service quality predict customer satisfaction and behaviour intentions in the sport tourism industry? An application of the SERQUAL model in an outdoors setting. Journal of Sport Tourism, Vol. 10 No. 2, pp. 101-111. Retrieved from: http://www.tandf.co.uk/journals/10.1080/14775080500223165

13. Meenagham, T. (2001). Understanding sponsorship effects. Psychology and Marketing, Vol. 18, pp. 95122. Retrieved from: http://onlinelibrary.wiley.com/doi/10.1002/1520-6793(200102)18:2\%3C95::AIDMAR1001\%3E3.0.CO;2-H/pdf

14. Morgan, M. \& Summers, J. (2005). Sports Marketing. Thomson: Australia. Retrieved from: http://books.google.co.za/books?id=RKn3jVW39gC\&printsec $=$ frontcover\&source $=$ gbs ge summary $r \& c a d=0 \# v=$ onepage $\& q \& \mathrm{f}=$ false

15. Mullin, B. J., Hardy, S. \& Sutton, W. A. (1993). Sport marketing Champaign, Human Kinetics: IL.

16. Oliver, R. L. (1997). Satisfaction: A behavioural perspective on the consumer. New York, NY: Irwin/McGraw-Hill,

17. Parasuraman, A, Zeithaml, V. A. \& Berry, L. L. (1988). SERQUAL: a multiple-item scale for measuring consumer perceptions of service quality. Journal of Retailing, Springs, pp. 12-40. Retrieved from: http://areas.kenan-flagler.unc.edu/Marketing/FacultyStaff/zeithaml/Selected\%20Publications/SERVQUAL$\% 20 \mathrm{~A} \% 20$ MultipleItem\%20Scale\%20for\%20Measuring\%20Consumer\%20Perceptions\%20of\%20Service\%20Quality.pdf

18. Pilus, A. H., M., Yusof, A. B., Bojei, JFauzee., M. S. O., Samah, B. A. \& Aziz, R. A. A. (2010). The relationship of sportscape, motivation, loyalty satisfaction and intention to watch Malaysia Cup football. American Journal of Scientific Research, No. 7, pp. 52-63. Retrieved from: http://www.eurojournals.com/ajsr 7 05.pdf

19. Potluri, R. M. \& Zleke, A. A. (2009). Evaluation of customer handling competencies of Ethiopian employees. African Journal of Business Management. Vol. 3 No. 4, pp 131- 135. Retrieved from: http://www.academicjournals.org/AJBM/PDF/pdf2009/Apr/Potluri\%20and\%20Zeleke.pdf

20. Sureshchandar, G. S., Rajendran, C. \& Ananthraman., R. N. (2002). The relationship between service quality and customer satisfaction- a factor specific approach. Journal of Services marketing, Vol. 16 No. 4, pp. 363-379. Retrieved from: http://www.emeraldinsight.com/0887-6045.htm

21. The Australian institute of criminology. (Not dated). Retrieved from: http://www.aic.gov.au/publications/current\%20series/rip/1-10/12.aspx

22. Theodorakis, N. D., Koustelios, A., Robinson, L. \& Barlas, A. (2009). Moderating role of team identification on the relationship between service quality and repurchase intentions among spectators of professional sports. Managing Service Quality, Vol. 19 No. 4, pp. 456-473. Retrieved from: www.emeraldinsight.com/0960-4529.htm

23. Theodorakis, N., Kambitsis, C., Laios, A. \& Koustelios, A. (2001). Relationship between measures of service quality and satisfaction of spectators in professional sports. Managing service quality, Vol. 11, No. 6, pp. 431-438. Retrieved from: http://www.emerald.com/ft

24. Wakefield, K. L. \& Blodgett, J. G. (1994). The importance of servicescapes in leisure service settings. Journal of Services Marketing, Vol. 8, No 3, pp. 66-76. Retrieved from: http://www.emeraldinsight.com/journals.htm?articleid=855732

25. Westerbeek, H. M. \& Shilbury, D. (2003). A conceptual model for sport services marketing research: Integrating quality, value and satisfaction. International Journal of Sports Marketing \& Sponsorship, Vol. 5, No. 1. Retrieved from: http://www.imrpublications.com/journal-landing.aspx?volno=5\&no=1

26. Westerbeek, H.M. (2001). Marketing across cultures: an investigation into place-specific dimensions of service quality in sport. Phd thesis, Deakin University, Melbourne, Australia. Retrieved from: http://dro.deakin.edu.au/view/DU:30023566 
27. Yoshida, M.\&James, J. D. (2010). Customer satisfaction with game and service experiences: antecedents and consequences. Journal of sport management, Vol. 24, pp. 338-361. Retrieved from:

http://www.humankinetics.com/AcuCustom/Sitename/DAM/067/243 Yoshida_Customer_satis.pdf

28. Yusof, A. \& See, L. H. (2009). Spectator perceptions of physical facility and team quality: A study of a Malaysian Super league soccer match. Research Journal of International Studies, Vol. 8. Retrieved from: http://www.eurojournals.com/rjis_8_13.pdf 
NOTES 